Kristina Misheva, PhD, Assistant Professor

Faculty of Law, University "GoceDelchev"

„KrsteMisirkov" No.10-A P.O. Box 201 Shtip 2000, Republic of Macedonia

kristina.miseva@ugd.edu.mk

\title{
THE INFLUENCE OF THE EU HEALTH POLICY ON THE PROCESS OF PUBLIC HEALTH SYSTEM REFORMS IN THE REPUBLIC OF MACEDONIA
}

\begin{abstract}
The public health system is a public service that aims to improve the quality of life of the citizens. Therefore, this kind of public service is crucial for normal functioning of any state system, alongside education and the other social services. In the context of the purpose behind this research and the context of the focus of the paper under the term 'health services' will be used to describe the primary, secondary and tertiary health protection, which means that the dental health protection and the pharmacy services will be out of the scope of this research. The analysis showed that the health services are categorically connected with the position, the organization, the management and funding of the health system (the legislation, the government bodies, the executives, the health institutions, the health services, human resources, citizens, IT service and other technical segments). This means that the influence of the socioeconomic development of the state reflects, directly, at the public health system.

The EU integration process of the Republic of Macedonia has showed that the existing health system was needed to be reconstructed (legally and institutionally) so it could be competitive, efficient and effective. During these decades, having in mind, the EU recommendations the national health policy framework was rapidly changed.

Through survey of the relevant literature, questionnaires and interviews made for the article we will try to give an answer if the parallel existence of the primary, secondary and tertiary public and private health system is justified having in mind the population of the country. Furthermore, should the secondary and tertiary segment of the public health system serve as back up to the private system, in a situation where there is a lack of doctors and other specialized medical staff, as well as lack of medical equipment to perform basic work. The question is how to find a financially sustainable public health system under which the health insured individuals get adequate and quality health service.
\end{abstract}

Key words: public healthcare, health system, reforms, patients' rights. 


\section{INTRODUCTION AND DEVELOPMENT OF THE PUBLIC HEALTH SYSTEM AND HEALTH PROTECTION LAW REGIME IN THE REPUBLIC OF MACEDONIA}

In 1991, after the breakup of Yugoslavia, Macedonia became an independent country, but the influence of the concept of socialist health insurance was held up for many years later. Namely, as in any democratic country, the Republic of Macedonia considers the social freedoms and rights of its citizen as fundamental human right. In addition, after the independency, the health protection remains as priority in the national policy and health strategy.

The right to health care is social right guaranteed by article 39 in the Constitution of the Republic of Macedonia „Every citizen is guaranteed the right to health care. Citizens have the right and duty to protect and promote their own health and the health of others". This means that every citizen may ask for service and health protection from the Macedonian health institutions, regardless of their employment status. As a result, in 1991, the Health protection Law, which nullified the Law on Healthcare from Socialist Republic of Macedonia (Official Gazette of SRM 10/83, 43/85,50/87, 27/88,36/89 and 42/90) and the Law on the conditions and manner of achieving reimbursement of health services, pointed on pages (Official Gazette of SRM No. 15/76) was passed. Respecting the principles of mutuality and solidarity the right to health protection through compulsory health insurance and voluntary health insurance was established. ${ }^{2}$

The Republic of Macedonia needed to overcome the consequences from the former system, which was not applicable in democratic state with unilateral governance. We inhered public health system that was good implemented by the geodemographic position, but hard to maintain. This model of mandatory health insurance system - socialistic insurance is funded from the Fund Budget (Health Insurance Fund), the Central budget and the incomes from the individual health insurers. ${ }^{3}$ However, the liquidity of the health system depends of the national economy, the employment of the population, the incomes of individuals and companies, etc. Yet, the design, creation and implementation of the health policy and public health system is still in the hands of the executive bodies (The Government, the Ministry of Health, the Health Insurance Fund and the public health

Article 34,35 and 36 of the Constitution of the Republic of Macedonia.

2 See article 3, Health protection Law, Official Gazette of the Republic of Macedonia No.38/91, 46/93, 55/95, 10/2004, 84/2005, 65/2005, 5/2007, 77/2008, 67/2009, 88/10, 44/11, 53/11).

3 The contributions from health insurance fall under the revenues of the off-budget funds under the Budget of the Republic Macedonia, which with the transfers from the central budget never show deficiency in performance. 
organizations). The citizens and the civil society in the area of the health care and health protection are not consulted, therefore their needs are not considered. This is one of the reasons why in general the health care system has overall not been efficient. However, at the end, the National health strategy and health institutions that are established should follow the Principle: finance should follow functions.

The Health protection law of 1991 had 11 amendments and additions. ${ }^{4}$ This enabled changes in the ownership structure of the institutions. For the first time formally was provided the private health care (establishment of private hospital organizations and services). The responsibilities and complexity of work in the institutions were re-defined, which in turn was used to determine the activities and powers of both public and private institutions. In 2000, the Health Insurance law was passed, which to date has been subject to a record 32 amendments. ${ }^{5}$ In 2007, the Ministry of Health of the Republic Macedonia adopted the National Health Strategy $2020^{6}$, which emphasized the need for reform in the Macedonian health care system and the need for improvement of the public health in accordance with international standards and rules. This strategic document prompted the adoption of a whole set of legal acts. In 2008, the Law on the Protection of Patients' Rights entered into force. ${ }^{7}$ In 2009 , the Law on health care records was also passed with a few amendments. ${ }^{8}$ In 2009 they start with implementation of the electronically Health Insurance Card. Till 2015-th R. Macedonia signed agreements with eight Member States on using the European Health Insurance Card. ${ }^{9}$ In 2010 the Public HealthLaw entered into force, which has been subject to several amendments as well. ${ }^{10}$ In 2012 the current Law on Health Care was passed, and up to today it has

4 The Health protection Law, Official Gazette of the Republic of Macedonia No.38/91, 46/93, 55/95, 10/2004, 84/2005, 65/2005, 5/2007, 77/2008, 67/2009, 88/10, 44/11, 53/11).

5 Law on health insurance, Official Gazette of the Republic of Macedonia No.25/2000; 96/2000, 50/2001, 11/2002,31/2003, 84/2005, 37/2006, 18/2007, 36/2007, 82/2008, 98/2008, 6/2009, 67/2009, 50/10, 156/10, 53/11, 26/12, 16/13, 91/13,187/13,43/14, 44/14, 97/14, 112/14, 113/14, $188 / 14,20 / 15,61 / 15,98 / 15,129 / 15,150 / 15,154 / 15,217 / 15,27 / 16$. Still , there is no official consolidated version on the Law.

6 URL=http://www.nationalplanningcycles.org/sites/default/files/planning_cycle_repository/the_former_yugoslav_republic_of_macedonia/health_strategy_2020.pdf. Accessed 20 February 2017

7 Patients right Law, Official Gazette of the Republic of Macedonia No. 82/08, 12/09, 51/11.

8 Law covering the records in health care, Official Gazette of the Republic of Macedonia, No. 20/2009, 53/11, 164/13, 150/15.

9 Commission Staff Working Document The Former Yugoslav Republic Of Macedonia Report 2015 , SWD(2015) 212 final , Brussels, 10.11.2015., pp. 34

10 Public Health Act, Official Gazette of the Republic of Macedonia , No. 22/10; 136/11; 144/14; $149 / 15$; 
been amendment over 10 times, ${ }^{11}$ The Law on Voluntary Health Care Insurance, ${ }^{12}$ and over 20 laws and numerous bylaws were also instituted. ${ }^{13}$

According to the current Law on health protection, the advancement of the effective treatment and early detection of diseases is done on three levels: primary secondary and tertiary level of health care. This demands a reorganization of responsibilities and share powers among healthcare facilities depending on the complexity of the needed health service and individual health practitioners' health offerings. The primary care is under municipal jurisdiction in coordination with the central government. However, in the secondary level, this situation opened up the opportunity for the establishment of private hospitals and institutions, and to strength up their position in the national health system. They increased the competition at state hospitals and institutes covering secondary health care. At the moment, legally there are several state institutions that offer secondary and tertiary healthcare. Specifically, according to a current analysis of the territory of Republic of Macedonia there is a University Clinical Center (university clinics and clinical hospitals) offering tertiary health protection. Specialized/clinical and general hospitals, (there are three hospitals in Tetovo, Shtip and Bitola), 13 general hospitals, several special hospitals, and health institutes that are providing specialist-consultative services. ${ }^{14}$

For the purpose of this article, in the beginning of 2017, we made a survey in the southeastern part of the country for which is competent the clinical hospital in Stipas a secondary health care sector (note: As we said at the beginning of this paper the dentists and the pharmacy sectors are excluded).The target group of 70 patients that have public health insurance was randomly chosen (the people that were waiting to be examine at the primary and at the secondary level health institutions). In the queues, most of them were women from 18 to 64 years (see table 1 and table 2), $77,1 \%$ with high education. Most of the questioned people are satisfied from the services from the chosen doctor in the primary health sector (table 3), highlighting as advantage saving time. Almost half of them $(48,6)$ said that they use public health services, but also more than a half $(51,1)$ are doing parallel checkups ( second opinion), using both public and private health services (see fig.1).

11 Law on Health protection, Official Gazette of the Republic of Macedonia No.43/12, 145/12, $87 / 13,164 / 13,39 / 14,43 / 14,188 / 14,10 / 15,61 / 15,61 / 15,154 / 15,192 / 1537 / 16$. This act has also been amended several times and, still, there is no consolidated version of this Law.

12 Law for voluntary health insurance, Official Gazette of the Republic of Macedonia NQ.145/12, 192/15

13 All Laws are published at the official web site of the Ministry of Health of The Republic of Macedonia, till 2015. For more see: URL=http://zdravstvo.gov.mk/zakoni-2/.

14 Official website of the Ministry of Health of the Republic of Macedonia, URL=http://zdravstvo.gov. mk/sekundarna_i_tercierna/, last updated 2015. Accessed 31 January 2017. 


\begin{tabular}{|l|l|c|c|c|c|}
\hline \multicolumn{5}{|c|}{ Table 1 Gender } \\
\hline \multirow{3}{*}{ Valid } & Male & 28 & 40,0 & 40,0 & 40,0 \\
\cline { 2 - 6 } & Female & 42 & 60,0 & 60,0 & 100,0 \\
\cline { 2 - 6 } & Total & 70 & 100,0 & 100,0 & \\
\hline
\end{tabular}

\begin{tabular}{|l|l|c|c|c|c|}
\hline \multicolumn{6}{|c|}{ Table 2. Age } \\
\hline \multirow{3}{*}{ Valid } & Frequency & Percent & Valid Percent & Cumulative Percent \\
\cline { 2 - 6 } & under 18 & 2 & 2,9 & 2,9 & 2,9 \\
\cline { 2 - 6 } & from 18 to 64 & 61 & 87,1 & 87,1 & 90,0 \\
\cline { 2 - 6 } & over 64 & 7 & 10,0 & 10,0 & 100,0 \\
\cline { 2 - 6 } & Total & 70 & 100,0 & 100,0 & \\
\hline
\end{tabular}

Table 3. Are you satisfied from the services of your chosen doctor primary health care?

\begin{tabular}{|l|l|c|c|c|c|}
\hline \multicolumn{2}{|c|}{} & Frequency & Percent & Valid Percent & Cumulative Percent \\
\hline \multirow{7}{*}{ Valid } & Yes & 34 & 48,6 & 48,6 & 48,6 \\
\cline { 2 - 6 } & Satisfactory & 26 & 37,1 & 37,1 & 85,7 \\
\cline { 2 - 6 } & No & 10 & 14,3 & 14,3 & 100,0 \\
\cline { 2 - 6 } & Total & 70 & 100,0 & 100,0 & \\
\hline
\end{tabular}

\section{Figure1}

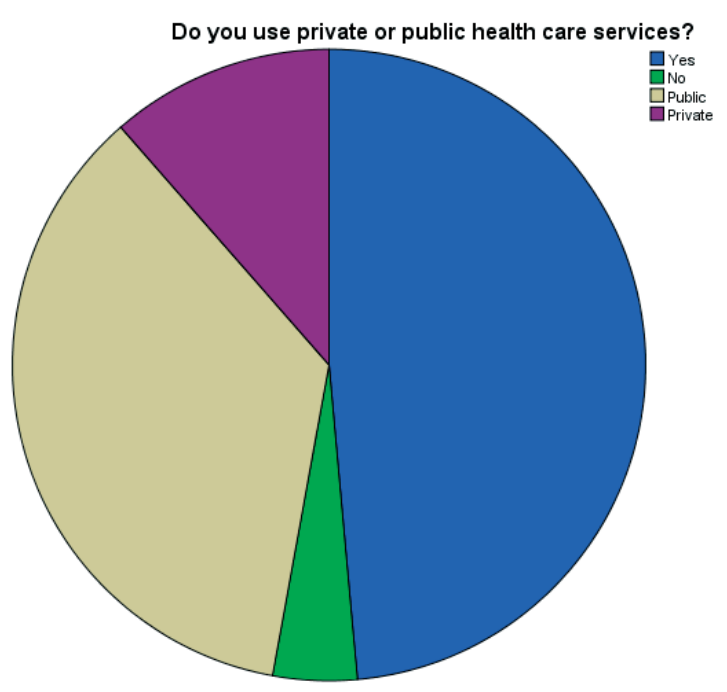


Only the patients from the primary level, through the doctor in the primary health care sector, may be directed at the secondary sector. Perhaps the crucial novelty in this entire system of legal, organizational and functional modernization is the Integrated National Electronic system for scheduling and recording of medical interventions, so called, "My Appointment". This system start with its implementation in 2013 and has several goals: electronic scheduling of medical check up, scheduling intervention and review in order to lessen the confusion and waiting lines in health care offices and facilities; the creation of unified and reliable database, quick and simple record updates on patient data; the creation of an electronic medical record (dossier); the setup of a quality health care service at the expense of reduced administrative work; the creation of a detailed timetable for the admission of patients in all doctors' offices; the introduction of new work processes through the introduction of electronic medical record, electronic prescription, electronic referral, electronic scheduling of examinations and other services. In addition, the system aims to reduce the number of duplicate examinations and interventions, establishing faster communication and consultation between the primary, secondary and tertiary health care, providing better quality of service and reduction of the risk of wrong professional decisions. Financial savings are also a consideration behind the plan. Electronic processing of documents will replace the current paper referrals and prescriptions. Accurate and timely data for all the segments covered by the health system, and the opportunity for patients to access their own information and useful data through the internet is also a goal. Still, the survey indicates that $42.9 \%$ are not satisfied with this concept (see table 4). Emphases couple situations as a weakness: that the people cannot chose the doctor specials that they prefer and very often they wait more than two -three months to appoint, and the second situation is that the appointed term in not in the line with the real situation at the hospital and the set time is extended (still there are long waiting lines). (See table 5). Furthermore, they are not satisfied from the quality of the serves they receive. (See table 6)

Table. 4 Are you satisfied from the „My appointment" concept?

\begin{tabular}{clc|c|c|c} 
& & Frequency & Percent & Valid Percent & Cumulative Percent \\
\hline \multirow{3}{*}{ Valid } & Yes & 15 & 21,4 & 21,4 & 21,4 \\
\cline { 2 - 6 } & Satisfactory & 25 & 35,7 & 35,7 & 57,1 \\
\cline { 2 - 6 } & No & 30 & 42,9 & 42,9 & 100,0 \\
\cline { 2 - 6 } & Total & 70 & 100,0 & 100,0 & \\
\hline
\end{tabular}


Table 5. Are the doctors ontime and efficent according „My appointment“ ?

\begin{tabular}{llc|c|c|c} 
& & Frequency & Percent & Valid Percent & Cumulative Percent \\
\hline \multirow{3}{*}{ Valid } & Yes & 23 & 32,9 & 32,9 & 32,9 \\
\cline { 2 - 6 } & Satisfactory & 31 & 44,3 & 44,3 & 77,1 \\
\cline { 2 - 6 } & No & 16 & 22,9 & 22,9 & 100,0 \\
\cline { 2 - 6 } & Total & 70 & 100,0 & 100,0 & \\
\hline
\end{tabular}

Table 6. Are you satisfied from the quality of the services that your receive at the hospital?

\begin{tabular}{llc|c|c|c} 
& & Frequency & Percent & Valid Percent & Cumulative Percent \\
\hline \multirow{3}{*}{ Valid } & Yes & 10 & 14,3 & 14,3 & 14,3 \\
\cline { 2 - 6 } & Satisfactory & 30 & 42,9 & 42,9 & 57,1 \\
\cline { 2 - 6 } & No & 30 & 42,9 & 42,9 & 100,0 \\
\cline { 2 - 6 } & Total & 70 & 100,0 & 100,0 & \\
\hline
\end{tabular}

Despite mentioned, we should underline, that the interviewed patients are complaining that the hygiene and the medical furniture are below average (the waiting rooms, toilets, beds and the sheets are not clean and old), the medical staff ( except the doctors)is not polite, most of the time there is deficit of the basic medical supplies and in some cases they are advice to buy on there one. On the other hand, there is new medical equipment that is not used in full capacity because there is not enough qualified doctors and healthcare staff, reconstruction of the existing buildings and building new ones are priority. ${ }^{15}$ Although, this survey was made in one region, more or less, reflects the overall situation in the state.

With this "avalanche" of legal acts and electronic / automated developments, relating to the health care and health system in general a radical turn in the conception of the national health and national health policy was created. But it become obvious that not much thought has been put into whether such an extensive legislative changes could be implemented and whether there is the de facto capacity for them to be realized in practice? Is this national health care strategy compatible with the lifestyle of the citizens and their current socio-economic situation? Will these permanent changes encourage a development and improvement of the currently established system or they will cause distortion in the overall health system?

15 In 2015, the Ministry of Health announced investment from 30.000.000 EUR for construction of new and modern hospital in Stip. URL=http://zdravstvo.gov.mk/klinichka-bolnica-shtip/. Accessed 15 December 2017. 


\section{REPUBLIC OF MACEDONIA AND POLICY ALIGNMENT WITH THE EU AND WHO}

The Republic of Macedonia has shown anopenness to international standards in the field of social rights by harmonizing and changing its legislation regarding fundamental human rights and citizens' health protection. ${ }^{16} \mathrm{After}$ independence, Macedonia has shown an interest to get closer to the European states and its continental law system, and within a few years, its integration to the European Union became a focal strategy. Considering the commitment of the Republic of Macedonia to the European Community, European Union and its member states signed the Stabilization and Association Agreement with the Republic of Macedonia in $2001^{17}$, first SAA in the region. By the SAA Agreement, the Republic of Macedonia is obliged to improve the level of health and safety protection of workers, using as a reference the levels of protection that exist in the European Community. ${ }^{18} \mathrm{In}$ 2006, based on official country reports, data and detailed descriptionsprovided from the relevant institutionsof the current Macedonian health system, ${ }^{19} \mathrm{WHO}$ European Regional office placed Republic of Macedonia as a country with transitional health system. ${ }^{20}$ In 2007, leaded by the EU health policy Health 2020 and WHO strategy and priorities, the Ministry of Health of Republic of Macedonia brought a Health strategy of the Republic of Macedonia 2020. The strategy cares out the vision of safe, efficient and just national Health Care System.

The health condition of the Republic of Macedonia is more or less at the level of the southeastern European countries, but far behind the EU member countries. ${ }^{21}$ Still, the last couple of years the Reports ${ }^{22}$ from the European Commission in the area

16 Public Health Act, Official Gazette of the Republic of Macedonia, No. 22/10; 136/11; 144/14; 149/15, 37/16.

17 Stabilization and Association Agreement between the European Communities and their Member States, of the one part, and the Former Yugoslav Republic Of Macedonia, of the other part, Council Of The European Union, 2001/0049 (acv). 6726/01. limite. yu 6. coweb 20, Brussels, March 2001, URL=https://eeas.europa.eu/sites/eeas/files/saa03_01_en.pdf.

18 See article 168 (3) TFEU [2008] OJ C115/123.

19 Health systems in transition, the Former Yugoslav Republic of Macedonia health system review, Vol.8, No.8, 2006.

20 URL=http://www.euro.who.int/_data/assets/pdf_file/0007/98890/E89275sum.pdf?ua=1. Accessed 12 December, 2016

21 Council Conclusions on Common values and principles in European Union Health Systems [2006] OJ C146/01.

22 Commission Staff Working Document The Former Yugoslav Republic Of Macedonia Report 2015, SWD(2015) 212 final , Brussels, 10.11.2015 and Commission Staff Working Document The Former Yugoslav Republic Of Macedonia Report 2016, SWD(2016) 362 final , Brussels, 09.11.2016 
of the health protection have a status of moderately prepared with recommendation to ensure efficient and high-quality healthcare. ${ }^{23}$

The free movement of people and goods emphasis the inequality of good health at Union level which imply the necessary to promote common health policy and coordination between the national programmes of the EU Member States. Furthermore, the Union and the member states foster cooperation with third countries and the competent international organizations in the sphere of public health. To foster the health of the European citizens, the Community has made numerous studies, many activities and adopted several programmes in the field of public health and in the field of health in generally. In 2003, these separate programmes were replaced by a single integrated EU Public Health Programme (Decision No $1786 / 2002 / \mathrm{EC})^{24}$, later with the Second Public Health Programme (Decision No $1350 / 2007 / \mathrm{EC})^{25}$ and the Third Programme in the field of health which is called Health for Growth (Regulation (EU) No 282/2014) ${ }^{26}$ established for 2014-2020. The Health for Growth Programme was build up on the two previous health programmes from 2003-2008 and 2008-2013. The current Programme efforts to fulfill several objectives: to promote health, to protect citizens from cross-border threads, to improve safer healthcare and to build up sustainable health systems. Additionally, to improve the quality of the health services, the patient rights and the health protection of the European citizens, the Community encourage cooperation and exchanging information in the field of public health between the Member States. ${ }^{27}$

When a Member State raises a specific public health problem in the field, which has been the subject of prior alignment measures, it shall bring it to the attention of the Commission, which shall immediately examine whether to propose appropriate measures to the Council. ${ }^{28}$ Furthermore, in accordance with article 168(6) the Council, on a proposal from the Commission, may adopt recommendations

23 Commission Staff Working Document The Former Yugoslav Republic of Macedonia Report 2015, Chapter 48, p. 68.

24 Decision No 1786/2002/EC of the European Parliament and of the Council of 23 September 2002 adopting a programme of Community action in the field of public health (2003-2008) [2002] OJ L 271.

25 Decision No 1350/2007/EC of the European Parliament and of the Council of 23 October 2007 establishing a second programme of Community action in the field of health (2008-13) [2007] OJ L $301 / 3$.

26 Regulation (EU) No 282/2014 of the European Parliament and of the Council of 11 March 2014 on the establishment of a third Programme for the Union's action in the field of health (2014-2020) and repealing Decision No 1350/2007/EC) [2014] OJ L86/1.

27 See Article 168 (3) TFEU [2012] OJ C326.

28 Article 114 , paragraph 8, Chapter 3-Approximation of Law , TFEU 
for the public health matters, in full respect of the responsibilities of the Member States for the design of their health policies, the institutional organization and delivery of health services and medical care. Public health matters fall in the area of shared competences between the Union and the Member State. ${ }^{29}$ In fact, the dual nature of the competences in the area of public health is reflected in the different types of measures that the EU can take. ${ }^{30}$ The EU action in public health seize to set up a high level of human health protection standards and sustainable public health system. The public health is crucial pillar for every develop society and the Treaty of Lisbon enhanced the importance of that, by building up a coherent public health system by encouraging cooperation between the Member States and lending support to their national health policies and actions. ${ }^{31}$ The EU health policy boost to prevent diseases and to improve and promote healthy lifestyle. The implementation of the Third Programme of EU`s action in the field of health in the Member States and participate countries gains to build up consist, equal and efficient health systems. In the line with the EU 2020 Strategy and the WHO priority objectives, the Union focuses on consolidation of the institutional and the legal framework in the field of public health, which implicates on the public health policies and activities in the Member States and the potential candidate countries for EU membership.

\section{CONCLUSION}

The health systems varied from county to country as a reflection of different demographic and socio-economic position, despite they are build up on similar common values and principals. Still, the Union support the Member States healthcare systems and policies, encourage cooperation and promotes the coordination between their national programmes and best practices.

29 See Article 4 , paragraph $2(\mathrm{k})$, Consolidated versions of the Treaty of European Union and the Treaty of the Functioning of the European Union - Consolidated version of the Treaty on the Functioning of the European Union - Protocols - Annexes - Declarations annexed to the Final Act of the Intergovernmental Conference which adopted the Treaty of Lisbon, signed on 13 December 2007, Official Journal C $326,26 / 10 / 2012$ P. $0001-0390$

30 See Article 168 (5) TFEU. 'The European Parliament and the Council, acting in accordance with the ordinary legislative procedure and after consulting the Economic and Social Committee and the Committee of the Regions may also adopt incentive measures designed to protect and improve human health and in particular to combat the major cross-border health scourges, measures concerning monitoring, early warning of and combating serious cross-border threats to health, and measures which have as their direct objective the protection of public health regarding tobacco and the abuse of alcohol, excluding any harmonisation of the laws and regulations of the Member States.'

31 See Article 168 (2) TFEU 
On the other hand, the current health care system in Republic of Macedonia has proved to be uncompetitive, inefficient, ineffective and without a clearly defined responsibilities of health institutions/organizations. There is a lack of coordination between authorities in-charge as well. As a result, some citizens in certain parts of the country are faced with unavailable and untimely health care system and public health services.

This gap in the quality of treatment is behind the revamp of the entire health system and the frequent amendments to the legislation which are ongoing, but ultimately destabilize the health system. The existence of private health facilities and specialty hospitals did not result in a spur of competitiveness among public institutions and hospitals to attempt to rival the private health sector; on the contrary, it resulted in collapsing the public system financially. Most of the citizens did not receive more options in choosing a better quality and more timely health care services, rather they were faced with an inequality in their ability to secure and upgrade their individual health and the health of their family (only higher income earners can afford private health services).

Naturally, the modernized health care system introduced certain improvements, such as: specialization and training of medical staff, better control over it, more effective patient records and in general, the application of health care improvement according to international standards, building and rehabilitating health care facilities, training of health personnel, providing equipment, essential medicines and supplies, etc.

Resent survey and analyses have shown that there is a functional separation between the primary, secondary and tertiary health protection on one hand and among the public and the private health systems on the other hand. So, the existing health system is based on a fragmentation and lack of communication between the health institutions (vertically / horizontally, state/private). Also, the annual 2015 reports from the World Health Organizations indicate that Macedonia is a country with the highest infant mortality rate, as well as the highest rate of death among pregnant women in the region. ${ }^{32}$

These numbers should put all stakeholders at a state of alarm. Having in mind the public health reform and the EU law on patients' health care rights, another aspect that needs to be explored is if the creators of the public health policy considered the birth rate / mortality ratio situation, or they were just trying to keep up with the European legislation regarding this issue.

32 URL=http://www.who.int/countries/mkd/en/. Accessed 30 November 2016. 
Having in mind the actual position of the health system seen through the survey and the interviewed people, maybe we should ask do we need to reform the reformed health system? The Republic of Macedonia needs a sustainable public health system, which will provide quality and equal services to every citizen. Citizens ought to enjoy the benefits of the health care services regardless of the place of living or their working position.

\section{REFERENCES}

\section{EU LAW AND INTERNATIONAL PUBLICATIONS}

1. TFEU [2012] OJ C326.

2. Council Conclusions on Common values and principles in European Union Health Systems [2006] OJ C146/01.

3. World health organization regional office for Europe: Health21- health for all in the 21-st century, Copenhagen, Series No.5.

4. Commission Staff Working Document the Former Yugoslav Republic Of Macedonia Report 2015, SWD (2015) 212 final, Brussels, 10.11.2015.

5. Commission Staff Working Document the Former Yugoslav Republic Of Macedonia Report 2016, SWD (2016) 362 final, Brussels, 09.11.2016.

6. Decision No 1786/2002/EC of the European Parliament and of the Council of 23 September 2002 adopting a Programme of Community action in the field of public health (2003-2008) [2002] OJ L271.

7. Decision No 1350/2007/EC of the European Parliament and of the Council of 23 October 2007 establishing a second Programme of Community action in the field of health (2008-13) [2007] OJ L301/3

8. Regulation (EU) No 282/2014 of the European Parliament and of the Council of 11 March 2014 on the establishment of a third Programme for the Union's action in the field of health (2014-2020) and repealing Decision No 1350/2007/EC) [2014] OJ L86/1.

\section{NATIONAL REGULATIONS AND ACTS}

1. National Health Strategy 2020, Ministry of Health of the R. Macedonia, Skopje, 2008.

2. Health systems in transition, the Former Yugoslav Republic of Macedonia health system review, Vol.8, No.8, 2006

3. Public Health Act, Official Gazette of the Republic of Macedonia No. 22/10; 136/11; 144/14; 149/15, 37/16.

4. Law on Health protection, Official Gazette of the Republic of Macedonia No.38/91, 46/93, 55/95, 10/2004, 84/2005, 65/2005, 5/2007, 77/2008, 67/2009, 88/10, 44/11, 53/11).

5. Law on Health protection, Official Gazette of the Republic of Macedonia No.43/12, 145/12, 87/13,164/13, 39/14, 43/14, 188/14, 10/15,61/15, 61/15, 154/15, 192/15 37/16. 
6. Patients right Law, Official Gazette of the Republic of Macedonia No. 82/08,12/09, 51/11.

7. Law on health insurance, Official Gazette of the Republic of Macedonia No.25/2000; 96/2000, 50/2001, 11/2002,31/2003, 84/2005, 37/2006, 18/2007, 36/2007, 82/2008, 98/2008, 6/2009, 67/2009, 50/10, 156/10, 53/11, 26/12, 16/13, 91/13,187/13,43/14, 44/14, 97/14, 112/14, 113/14, 188/14, 20/15, 61/15 , 98/15, 129/15, 150/15, 154/15, $217 / 15,27 / 16$.

\section{WEBSITE REFERENCES}

1. World Health Organization, URL=http://www.who.int/countries/mkd/en/. Accessed 30 November 2016.

2. Ministry of Health of The Republic of Macedonia, URL=http://zdravstvo.gov.mk/ sekundarna_i_tercierna/. Accessed 31 January 2017.

3. Ministry of Health of the Republic of Macedonia, URL=http:/www.nationalplanningcycles. org/sites/default/files/planning_cycle_repository/the_former_yugoslav_republic_of_macedonia/health_strategy_2020.pdf. Accessed 20 February 2017

4. Ministry of Health of the Republic of Macedonia,

URL=http://zdravstvo.gov.mk/zakoni-2/. Accessed 01. December 2016. 